\title{
Comparative Analysis and Enlightenment of Employment Intentions of Chinese and American Financial Management Majors
}

\author{
Zhi $\mathrm{Li}^{1, \mathrm{a}, 1 \mathrm{st}}$, Haowei $\mathrm{Ti}^{\mathrm{i}}$,b,2nd \\ ${ }^{1}$ Beijing Wensheng Technology Co.,ltd, Board of Directors, Beijing, China \\ ${ }^{2}$ Hong Kong Asia Business College, International Academic Exchange Center, Hong Kong,China
}

\begin{abstract}
The development and improvement of the financial management profession plays a vital role in promoting the growth of talents, smooth employment and successful entrepreneurship in universities. The financial management profession of American college students started early and is very mature. This paper makes a detailed comparison of the employment intentions of financial management majors from multiple angles, and obtains the diversification and multi-channelization of the employment intentions of American financial management majors. It will provide a reasonable reference for the development and improvement of the employment intention and possible development direction of college students majoring in financial management in China.
\end{abstract}

\section{Introduction}

With the rapid and changeable development of the times, many industries that adapt to social development have also spawned, and the corresponding learning professions will keep up. The financial management profession is a new type of profession. The prosperity of the times has promoted the development of society. Colleges and universities offer corresponding courses, which can keep up with the pace of the times and cultivate talents who adapt to society. This is the common progress of colleges and students and the only way for social development. After China joined the WTO, it needs more talents in this field. It must not only have theoretical knowledge reserves, but also modern management concepts and practical learning.

\section{The development trend of financial management profession}

\subsection{Current status of the financial management profession}

The development of a country requires not only the introduction of new technologies, but also the selfdetermination of transformation, especially in terms of personnel training. Only when management professionals are trained, can self-transformation and social talent needs be met. When cultivating talents in this area, students majoring in financial management must not only learn about management knowledge, but also cultivate management capabilities, but also learn about business management, economics and trade, laws and regulations and other aspects. Because students majoring in financial management need knowledge in these areas in their future employment. ${ }^{[4]}$ College students respond to the needs of the job and the company's talents. Therefore, in colleges and universities, for the courses developed by financial management majors, universities need not only to develop general business management courses, but also to develop business management, strategic marketing, market consumer psychology, economics and trade, market research, and customer relations. Advanced marketing management content such as management and integrated marketing. Both new knowledge and traditional management knowledge need to be learned in this major.

\subsection{The development trend of financial management profession}

It is the most basic for college students to learn theoretical knowledge, but also on the basis of theory, the most important thing is to be able to practice. In college courses, the courses for the major can be combined with teaching methods such as case teaching and interactive teaching, allowing students to practice in simulated scenarios. ${ }^{[5]}$ When the students of this major can master theoretical knowledge and practical ability, they can be better qualified for social jobs. A talent who adapts to the development of modern society must have good physical and psychological qualities, as well as high professional ethics and professionalism. Only in this way can students majoring in 
financial management adapt to the requirements of modern management and become talents needed by society.

\section{Employment intentions of college students majoring in financial management in China and the United States}

\subsection{Employment intentions of college students majoring in financial management in China}

When college students majoring in finance in China are employed, they will pay more attention to the salary of the post. In the United States, college students in this major pay more attention to the spatial nature of their positions when they are employed. ${ }^{[6]}$ Although there are many differences in the employment intentions of college students in this major between the two countries, there is also the same thing, that is, they both want to do work related to their major. Whether it is a private enterprise, a state-owned enterprise or a selfemployment, I hope that my future work is related to my major.

Table 1 Employment intention and employment rate of financial management related majors

\begin{tabular}{|c|c|}
\hline Specialized subject & Employment rate \\
\hline $\begin{array}{c}\text { Business } \\
\text { Administration }\end{array}$ & $64 \%$ \\
\hline $\begin{array}{c}\text { Business } \\
\text { Management }\end{array}$ & $72.03 \%$ \\
\hline $\begin{array}{c}\text { International E- } \\
\text { commerce } \\
\text { Management }\end{array}$ & $84.18 \%$ \\
\hline $\begin{array}{c}\text { Real Estate } \\
\text { Management }\end{array}$ & $73.82 \%$ \\
\hline $\begin{array}{c}\text { Financial } \\
\text { Management }\end{array}$ & $80.97 \%$ \\
\hline $\begin{array}{c}\text { Investment } \\
\text { Management }\end{array}$ & $70.07 \%$ \\
\hline
\end{tabular}

Regarding the employment intentions of the financial management major, the professional direction and employment rate are: business administration $64 \%$, business management $72.03 \%$, international e-commerce management $84.18 \%$, real estate management $73.82 \%$, financial management $80.97 \%$, investment management $70.07 \%$. College students understand the employment situation and can better control their employment mentality. There are very few college students who are not under pressure. Most college students majoring in financial management are under employment pressure, and $44.6 \%$ of college students majoring in financial management are under pressure. Most of these college students are college students who do not understand the employment situation. Because he is anxious about his own employment, and at the same time he does not understand the employment trend of his major. Therefore, when facing employment, the psychological pressure and anxiety of college students majoring in financial management are more serious. After discovering the differences in employment intentions between China and the United States, financial management majors were discussed. This is conducive to the improvement of the mode of continuing to cultivate talents in universities, especially for the reasons behind the differences and influencing factors. There are some differences between college students majoring in financial management in China and those majoring in financial management in the United States in terms of their employment intentions after graduation, specifically in the following three aspects. First of all, the employment intentions of Chinese financial management college students are biased towards entering state-owned enterprises and institutions, while the US financial management college students' employment intentions are biased towards entering private enterprises and selfemployment. ${ }^{[7]}$ In response to this difference, the enlightenment I got is to pay attention to cultivating the selfconfidence of Chinese financial management college students to improve their abilities. Colleges and universities can develop corresponding courses to help college students improve their confidence and make their own career plans. For American college students majoring in financial management, we can learn how to cultivate their own abilities. The second difference is that Chinese college students in this major are more inclined to have more stable employment. In the United States, college students in this major are more inclined to find jobs that can be challenging.

\subsection{Employment intentions of American financial management college students}

Table 2 Employment intentions of American financial management college students

\begin{tabular}{|c|c|c|c|c|}
\hline $\begin{array}{l}\text { Employment } \\
\text { intentions }\end{array}$ & Gender & $\begin{array}{c}\text { Private } \\
\text { Enterprise }\end{array}$ & $\begin{array}{c}\text { Self- } \\
\text { employed }\end{array}$ & Others \\
\hline \multicolumn{2}{|c|}{ Male } & $56 \%$ & $30 \%$ & $14 \%$ \\
\hline \multicolumn{2}{|c|}{ Female } & $70 \%$ & $11 \%$ & $19 \%$ \\
\hline
\end{tabular}

Among American college majors, the most popular is financial management. Graduates of this major account for about $8 \%$ of the total number of American graduates. Among financial management graduates, $56 \%$ are men and $44 \%$ are women. The second is business, accounting for about $5 \%$ of American graduates, of which $61 \%$ are men and $39 \%$ are women. The knowledge learned by the financial management major is cross-professional and comprehensive talent training. For American financial management college students, the employment intentions are very broad. Some of them want to start their own business, some want to enter a private company, and some want to do other industries. No matter what kind of job it is, American college students majoring in financial management can develop their own communication skills and the ability to adapt to changes.

\subsection{Comparison of employment intentions of Chinese and American financial management college students}

There are some differences between college students majoring in financial management in China and those majoring in financial management in the United States in 
terms of their employment intentions after graduation, specifically in the following three aspects. The first aspect is: China's financial management majors are inclined to enter state-owned enterprises and institutions, while American financial management majors are inclined to enter private companies and start their own businesses. The difference in this aspect is related to the economy and job market of each country. First of all, when college students majoring in financial management in China are employed, they will consider whether their abilities match their positions, as well as whether their employment competitiveness is sufficient. For American college students majoring in financial management, they are more likely to consider whether they can apply what they have learned to enter private companies and entrepreneurship. These are the employment intentions of American college students in that major. The second difference is that college students majoring in finance in China are more inclined to have more stable employment, while college students in the United States are more inclined to find employment that can be challenging. To a large extent, this is because the education characteristics of the two countries are different. Let college students recognize the society's demand for talents and the reality of employment now. It will not only allow college students to see the society's requirements for talents, but also allow them to prepare for the conditions required by their favorite employment positions. When college students are employed, they will inevitably face the contradiction between selfexpectations and reality. Some students have particularly high expectations for employment, such as high wages and low wages. ${ }^{[3]}$ Only a few college students can work in such jobs that meet their expectations. Because this kind of jobs is small and competition is great. Basically, other college students are not in their desired jobs, so they will feel disappointed. Because college students have only entered society, the pressure of work and the sense of psychological loss will increase the psychological pressure of graduated college students. ${ }^{[8]}$

College students' accurate positioning of themselves helps college students to match effectively when choosing their own jobs. It is particularly important for college students to accurately position themselves, because inaccurate positioning is the main reason for the unsuccessful employment of college students. Through their own efforts and the education and knowledge they received during university, college students majoring in financial management can improve their learning ability and learn to supervise themselves. It can contribute to society for future development, and it can also realize its own ideals and goals. Anxiety makes them feel heavy and nervous when choosing jobs, especially some college students from remote areas, or introverted, or have physical defects, or poor academic performance, especially female college students. The employment of college students is developing towards objective reality. The vast majority of college students majoring in financial management adopt a "strengthstrength" attitude in employment and selection, relying on their comprehensive abilities to find ideal and ideal employers' benign psychological qualities and abilities. Therefore, it is very important for college students to recognize employment trends.

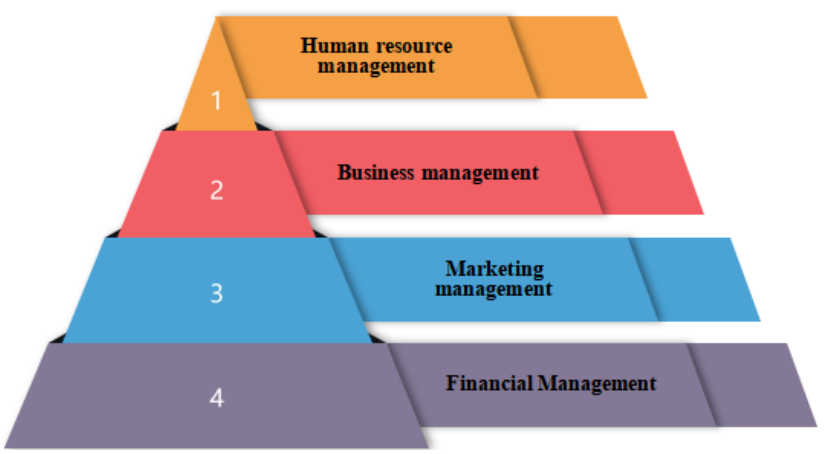

Figure 1.Employment types of employment intentions of financial management majors in Chinese universities

After graduation, students with financial management majors hope to be able to work in companies. To be engaged in financial marketing is to make decisions that are beneficial to the development and promotion of the company, as well as to maximize market returns and minimize asset consumption. ${ }^{[2]}$ At the same time, they must also take into account the company's market sales and the spread of brand effects. In short, financial management majors engaged in this employment direction pay more attention to the overall ability level display, and must have relevant theoretical knowledge, and corresponding practical work management experience. Only when financial management majors have perfect self-capacity reserves and are competent for the position, then this type of employment intention is a good job choice for financial management majors.

\section{Enlightenment research}

In view of the results of the comparison, the enlightenment obtained is: in the teaching process, teachers should encourage students to explore by themselves, cultivate their own abilities, teach students in accordance with their aptitude, and give students opportunities to practice. ${ }^{[1]}$ Courses for finance majors can be combined with teaching methods such as case teaching and interactive teaching, allowing students to be in a simulated scene. When students majoring in finance can master theoretical knowledge and practical ability, they can be better qualified for social jobs. The key to achieving advanced management goals for colleges and universities is to grasp the talent management mechanism and cultivate a large number of talents with modern management qualities. Due to the complexity of financial management science, managers are required not only to have excellent organizational, coordination, analysis, judgment and innovation capabilities, but also special qualities and courage.

Employment guidance for college students majoring in financial management is very important, especially the guidance and education conducted by college teachers. With the development of modern society, it is incomplete to provide employment guidance for college students through simple theoretical guidance. ${ }^{[9]}$ Therefore, it is necessary to combine the excellent teaching methods of this major in China and the United States to better provide guidance services. In terms of cultivating the employment confidence of college students majoring in financial management, college teachers can carry out certain courses to teach college students majoring in financial management to establish a 
correct outlook on employment when seeking employment. Employment outlook is an attitude towards employment. When facing employment, college students majoring in financial management must establish a correct outlook on employment. Let college students see clearly the development trend of the entire society and the changes in the employment situation. Only when they understand the overall situation can they be fully prepared. At the same time, colleges and universities set up certain courses to enable college students to correctly understand their own advantages and disadvantages in job hunting. In this way, financial college students will not have high expectations in their hearts when they are employed, and at the same time they will not underestimate their own strength and abilities.

\section{Conclusion}

When discussing the employment intentions of college students majoring in financial management, we should also pay attention to the problems of their own career planning of college students majoring in financial management. Colleges and universities can set up career planning courses in students' courses. Under the professional guidance of teachers, students can clearly understand their own employment advantages to develop. ${ }^{[10]}$ Finance majors understand their underemployment aspects to correct them, and at the same time can concentrate on vocational training. In order for students to obtain vocational qualifications, because obtaining vocational qualifications is very important for employment preparation. When obtaining employment, the vocational qualifications possessed by students are also a core competitiveness, which can provide students with more choices for employment.

For college students majoring in financial management, it is very important to prepare well for the job application. Mobilizing the power of society and schools to provide free training and assistance to college students will play a very important role in improving their professional competitiveness and achieving employment. The development and improvement of the financial management major plays a vital role in promoting the growth, successful employment and successful entrepreneurship of financial management majors in universities. The financial management profession of American college students started early and is very mature. This paper makes a detailed comparison of the employment intentions of financial management majors from multiple angles, and obtains the diversification and multi-channelization of the employment intentions of American financial management majors. It provides a reasonable reference for the development and improvement of the employment intention and development direction of college students majoring in financial management in China.

\section{Acknowledgment}

I want to sincerely thank my friend Prof. Haowei Ti. From the topic selection, experimentation, writing, revision and finalization of the paper, Prof. Haowei Ti has devoted a lot of hard work and sweat. His rigorous academic attitude has a deep influence on me, and his charisma of charisma is a model for me to learn from. It is unforgettable that Prof. Haowei Ti's perseverance and persuasive teaching in learning, care and help in life, made me gradually find my interest in learning and initially experience the joy of scientific research. He expanded my horizons, broadened my thinking, and decided the future direction of development. I am very grateful for the help and care given by Prof. Haowei Ti during the exam, and for giving me encouragement and guidance when I am confused.

\section{References}

1. Liu Rui. College business management talent training methods and employment exploration [J]. Modern Enterprise, 2020 (01): 136-137.

2. Chen Qin, Chen Jing. Exploring the training model of outstanding talents in applied business management under the background of excellence plan $[\mathrm{J}]$. Education Modernization, 2019, 6 (91): 3-5.

3. Yao Yiying. Reflections on the employment competitiveness of undergraduates in business administration in universities and their promotion [J]. Chinese and Foreign Entrepreneurs, 2019 (27): 167.

4. Yu Zhun. Analysis and reflection on the current situation of China's business administration under the new economic situation [J]. China Business Review, 2019 (13): 113-114.

5. Yang Lina. Research on the cultivation and characteristics of American higher education professionals [D]. Hebei University, 2019.

6. Xue Qianqian. Exploring a new model for training applied talents in business administration [J]. Chinese and foreign entrepreneurs, 2019 (14): 202.

7. Liu $\mathrm{Pu}$, Zeng Huachun, Zhang Rishang. Current situation of employment ability of college students majoring in business administration and countermeasures [J]. Education Teaching Forum, 2018 (39): 43-44.

8. Li Chunbo. Research on the training model of entrepreneurial talents in business management $[\mathrm{J}]$. Heilongjiang Education (Higher Education Research and Evaluation), 2018 (04): 69-70.

9. Yan Wanyu. Research on the status quo, problems and countermeasures of business management professional internship [J]. Modern Marketing (Late Journal), 2018 (02): 123-124

10. Xue Haizhou, \& Zhao Wei. (2017). Comparative Analysis and Enlightenment of Sino-US Financial Industry Operation and Supervision System-From the Perspective of Financial Crisis and Asset Securitization. Macroeconomic Research, 000 (002), 131-136. 